\title{
Sac Kalıplama Prosesinde DD13 ve S355MC Malzemelerin Yırtılma Probleminin İncelenmesi ve Çözümü
}

\author{
Melih Tuyan ${ }^{1 *}$, Ahmet Demirer $^{2}$ \\ ${ }^{1}$ Teknorot Otomotiv Ürünleri Sanayi, Araştırma ve Geliştirme Merkezi, Düzce, Türkiye (ORCID: 0000-0001-8474-2148), melih.tuyan@teknorot.com \\ ${ }^{2}$ Sakarya Uygulamalı Bilimler Üniversitesi, Lisansüstü Eğitim Ens., İmalat Müh. Böl., Sakarya, Türkiye (ORCID: 0000-0003-1252-9203), ademirer@subu.edu.tr
} (İlk Geliş Tarihi 19 Ekim 2020 ve Kabul Tarihi 24 Aralık 2020)

(DOI: $10.31590 /$ ejosat.828066)

ATIF/REFERENCE: Tuyan, M., \& Demirer, A. (2020). Sac Kalıp Prosesinde DD13 Ve S355MC Malzemelerin Yırtılma Probleminin İncelenmesi Ve Çözümü. Avrupa Bilim ve Teknoloji Dergisi, (20), 872-880.

\begin{abstract}
Öz
$\mathrm{Bu}$ çalışmada otomotiv süspansiyon sistemi elemanı olan sac salıncak kollarınım üretiminde kullanılan DD13 ve S355MC kalite sacların, üretimde karşılaşılan yırtılma probleminin çözüm süreçleri araştırılmış ve problemin çözümü gerçekleştirilmiştir. Çalışmada Autoform yazılım programı yardımıyla gerçekleştirilen analiz çalışmalarında yırtılmaya maruz kalacak kritik bölgeler tespit edilerek, geometride bazı iyileştirmeler yapılmıştır. Çalışmanın sonraki aşamasında her iki malzeme için de yırtılmanın gözlendiği bölgede oluşan çentik etkisinin giderilmesi için parlatma işlemi yapılmıştır. Parlatma sonrasında DD13 için yırtılma probleminin boyun verme eğiliminde olduğu, S355MC malzemesinde ise yırtılma probleminin azaldığı gözlenmiştir. Bir sonraki aşamada, her iki malzemeye sürtünmeyi azaltmak için kalıp yağlayıcı teflon film kullanılmıştır. DD13 malzemesi için yırtılma problemi tamamen giderilirken, S355MC malzemesinde boyun verme ve yırtılma problemleri azda olsa devam etmektedir. Son aşamada yırtılma problemi giderilemeyen S355MC malzemesinin kritik bölgesine 1sıl işlem uygulanmış ve yırtılma problemi giderilmiştir. Çalışmalara ek olarak elde edilen hatasız sac salıncak parçalara $\pm 380 \mathrm{kgf}$ yük altında 500.000 çevrim ile uygulanan yorulma testleri sonrasında parçalarda herhangi bir hasar gözlenmemiştir.
\end{abstract}

Anahtar Kelimeler: DD13, S355MC, Kalıp Yağlayıcı, Sac Kalıplama, Yırtılma Hasarı.

\section{Investigation and Solution of Tearing Problem of DD13 and S355MC Materials in Sheet Molding Process}

\begin{abstract}
In this study, the solution processes of the tearing problem encountered in production of DD13 and S355MC quality sheets used in the production of sheet metal wishbone arms, which are an element of the automotive suspension system, were investigated and the solution of the problem was realized. In the study, critical areas that will be exposed to tearing were determined in the analysis studies performed with the help of Autoform software program and some improvements were made in geometry. In the next stage of the study, polishing was carried out for both materials to remove the notch effect in the area where the tear was observed. It was observed that the tearing problem tended to neck for DD13 after polishing, while the tearing problem for S355MC was observed to decrease. In the next step, a mold lubricating teflon film is used to reduce friction on both materials. While the problem of tearing is completely eliminated for DD13 material, necking and tearing problems remain in S355MC material. In the last stage, the tearing problem could not be solved, the critical area of the S355MC material was heat treated and the tearing problem was solved. In addition to the studies, no damage was observed on the parts after the fatigue tests applied with 500,000 cycles under $\pm 380 \mathrm{kgf}$ load on the error-free sheet wishnone parts.
\end{abstract}

Keywords: DD13, S355MC, Mold Lubricator, Sheet Molding, Tear Damage.

\footnotetext{
${ }^{1}$ Sorumlu Yazar: Teknorot Otomotiv Ürünleri Sanayi, Ar-Ge Merkezi, Düzce, Türkiye, ORCID: 0000-0001-8474-2148, melih.tuyan@teknorot.com
} 


\section{Giriş}

Endüstride sac kalıplama prosesi halen hızlı şekillendirme yöntemlerinden biri olarak yoğun biçimde kullanılmaktadır. Sac kalıplamada kesme, bükme işlemlerin dışında derin çekme ve sı̆̆ çekme işlemleri sac kalıpçılığında parçanın formuna göre uygulanır. Sac kalıpçılığı bilhassa otomotiv sektöründe araçların farklı parçalarının hızlı şekillendirilmesinde tercih edilmektedir. $\mathrm{Bu}$ çalışmada otomotiv süspansiyon sistemindeki sac salıncak parçasının kalıplama prosesinde gerçekleşen yırtılma problemi ele alınarak çözümüne yönelik çalışma gerçekleştirilmiştir. Otomotiv süspansiyon sistemleri, hareket halindeki araç içerisinde seyahat eden kişi ya da cisimleri emniyetli ve konforlu bir sürüş deneyimi kazanması için geliştirilmiş bir sistem olup günümüzde birden fazla süspansiyon çeşitleri bulunmaktadır. Yol şartlarından kaynaklı sarsıntı ve titreşimin araç içerisine iletimini engelleyen en önemli unsur süspansiyon sistemleridir. Günümüz ihtiyaçlarından kaynaklı olarak süspansiyon sistemleri gelişme göstermeye devam etmektedir [1-2].

Günümüzde modern binek araçların birçoğunda süspansiyon sistemlerinde ortak parçalar; travers, amortisörler, yaylar, akson, direksiyon kutusu, rot mili, rot başı, denge çubukları, rotil-burç ve salıncak kolundan oluşmaktadır. Süspansiyon sisteminde tekerin yola basması ve tekerin yukarı-aşağı hareketini sağlayan salıncak kollarıdır [3]. Salıncaklar, döküm teknolojisi, dövme teknolojisi ve sac kalıplama olarak üç farklı metot ile imal edilebilir. Çoğunlukla şase ile arasındaki bağlantı salıncaktaki burçlar ile yapılırken, teker ile arasındaki bağlantı akson-rotil vasıtasıyla yapılmaktadır (Şekil 1) [4].

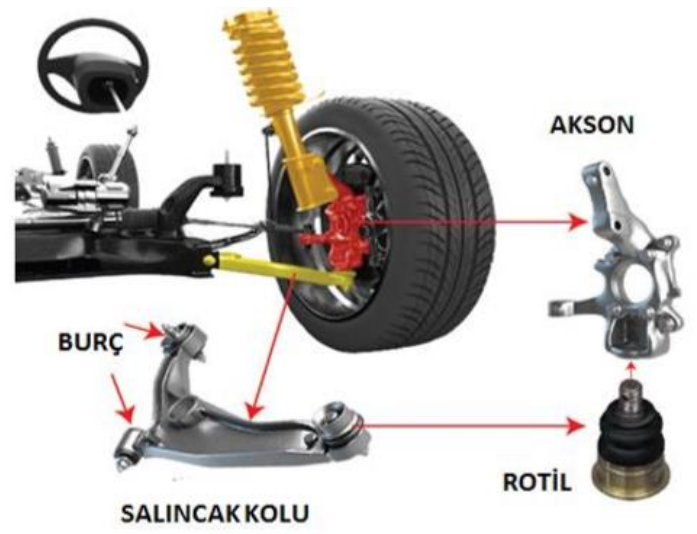

Şekil 1. Sac salıncak kolu [4]

Sac metallerin şekillendirilmesinde kullanılan yöntemlerin başında, kalıpta şekillendirme yöntemi gelir. Günümüzde beyaz eşya, otomotiv, havacılık, makine imalatı, tarım aletleri vb. birçok alanda kullanılan araç ve gereçlerin imalatında yaygın bir şekilde kullanılmaktadır. Çoğunlukla kalıp üzerine yerleştirilen levha ya da şablon haldeki sac malzeme, zımbanın üzerine gelen kuvvet etkisi ile istenilen şekillerdeki kalıp boşluğuna sıvanarak kalıbın şeklini alması işlemidir. $\mathrm{Bu}$ aşamada malzemede oluşabilecek gerilmeler malzemenin mekanik özellerini aşması halinde incelme-yırtılma eğilimi sergileyerek hasara uğrar [5].

Sac malzemelerin, üretiminde olası hataların öngörülmesi; kalıp henüz tasarım aşamasında iken tespit edilebilir. Bunun tespiti gümümüzde analiz programları ile mümkündür. Malzeme üzerindeki birim şekil değişimlerinin tespit edilmesi ile şekillendirme sınır eğrileri oluşturulur (Şekil 2), bu eğrilerin analiz programlarına malzeme tanımlamaları yapılarak üretimde karşılaşılacak hataların tespitini mümkün kılmaktadır. Bu eğriler ilk olarak Keeler ve Backofen tarafından sac malzemelerin şekillendirilebilirliğini değerlendirmek için ortaya atılmıştır [6].

Vishwajeet ve Uday [7] düşük karbonlu sac metallerin şekillendirme sınır eğrilerinin geliştirilmesi için yaptıkları deneyler neticesinde, şekillendirme sınır eğrisinin altındaki ve üstündeki tüm olasılıkları deneysel olarak incelemiş ve bu eğrilerin doğruluğunu ispat etmiştir.

Şekillendirme sırasında, sac malzeme başlangıçta kalınlık boyunca homojendir, şekillendirme sonrasında ise bölgesel olarak incelmektedir. Deformasyonun fazla olduğu bölgeler kopmaya ramak kala yani kopmak üzeri iken hemen öncesinde malzemenin kesiti aşırı derecede incelebilir. Yırtılma başlangıcı kabul edilen bu bölgeye boyun vermiş bölge denir. Yapısal olarak zayıflamaya neden olması sonucu boyun vermenin oluşması bir hasar olarak kabul edilmektedir [8]. Bu nedenle endüstride sac salıncak kolu üretiminde kullanılması uygun farklı türlerdeki sac malzemelerin üretim süreçleri gözden geçirilmeli ve bu süreçte karşılaşılan problemlerin çözümü araştırılmalıdır. Böylece farklı sac malzemelerin kullanılarak gerçekleştirilen sac salıncak kolu ürünlerin hızlı, hatasız ve kaliteli olmaları sağlanmalıdır.

$\mathrm{Bu}$ çalışmada DD13 ve S355MC kalitede iki farklı malzemelerin sac kalıplamadaki yırtılma hasarı otomotivde kullanılan sac salıncak kolu üzerinden gerçekleştirilmiştir. Sırasıyla öncelikle parça geometrisinin analizleri Autoform programı ile gerçekleştirilmiş ve malzemede oluşacak kritik gerilmelerin yerleri tespit edilmiştir. Öncelikle, geometride tekrarlı düzeltmeler yapılarak minimum gerilmenin elde edileceği geometri belirlenmiştir. Belirlenen geometri ile yapılan analizlerde oluşabilecek olası yırtılma hasarları üretim esnasında da karşılaşılmıştır. Karşılaşılan problemin çözümüne yönelik olarak; farklı malzeme kullanılması, proseste parametrelerin değiştirilmesi ve bazen de farklı üretim yöntemlerinin uygulanması gerekebilmektedir. Çalışmada yırtılma hasarının gerçekleştiği otomotiv süspansiyon sistemlerinde sac salıncak kolu ele alınarak farklı malzeme ve proses şartlarının ürün üzerindeki etkileri incelenmiş ve yırtılma hasarının çözümüne yönelik adım adım ilerleme gerçekleştirilmiştir. Üretim aşamasında uygulanan yöntem ve sırası malzeme ve yöntem kısmında geniş bir şekilde ele alınmıştır.

\section{Malzeme ve Yöntem}

Geniş şekillendirme yelpazesine sahip olmasının büyük avantajı ile hemen hemen her sektörde önemli ölçüde yer kaplayan sac malzemelerin üretim yöntemleri; haddeleyerek şekillendirme, gererek şekillendirme, derin çekme, sı ğ çekme, kauçukla şekillendirme, sıvama, süper plastik şekillendirme, yüzey çekiçleyerek şekillendirme, patlama ile şekillendirme, elektromanyetik şekillendirme ve kalıplama gibi özel prosesler ile üretimi mevcuttur. Sac kalıplama prosesi halen hızlı şekillendirme yöntemlerinden biri olarak kullanılmaktadır. Derin çekme ve sı̆̆ çekme işlemleri sac kalıpçılığında parçanın formuna göre uygulanmakta olup proses esnasında sacların yoğun çekildiği plastik deformasyonun en fazla gerçekleştiği bölgelerde uzama, boyun verme ve yırtılmalar görülmektedir [9].

Zamanla artan talep üzerine otomotiv üreticileri imalatta karşılaşacakları problemleri imalat aşamasında ara operasyonlar ile çözmek, kapasite artırımı için oldukça önem arz etmektedir. Üretim kapasitelerinin artması ile sac metallerin kullanım alanlarının genişlemekte olduğunu görmekteyiz. Hafifliğinin 
yanında, yüksek dayanımlı sacların şekillendirilebilirliği kontrol edilebilir olması ile otomotiv endüstrisinde geniş bir yelpazede kullanılmaktadır.

Son yıllarda artan sac şekillendirme işlemleri sonrasında üretimde karşılaşılan hataların erken tespiti için sonlu elemanlar yazılımı yaygın olarak tercih edilmektedir. Yüzeydeki birim şekil değişimlerinin tespiti ile şekillendirme sınır eğrileri (Şekil 2) elde edilerek sonlu elemanlar yazılımına malzeme girdileri işlenmesiyle, üretimde karşılaşılacak hataların erken tespitini mümkün k1lmaktadır [10].

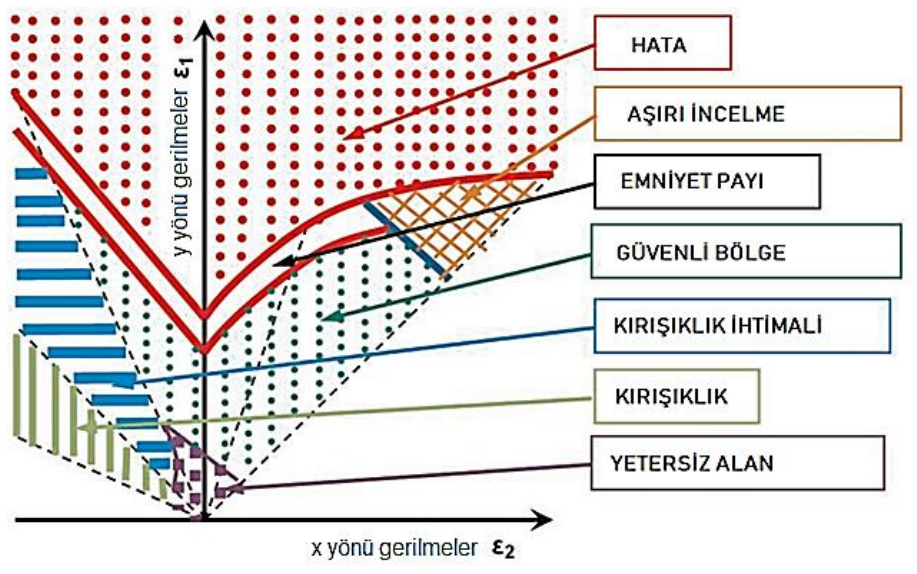

Şekil 2. Şekillendirme sınır ĕgrileri - FLD (Forming Limit Diagram)[10]

Çalışmada kullanılan sac salıncağa ait gövde sacı $2 \mathrm{~mm}$ et kalınlığına sahip, DD13 ve S355MC sac malzemeler ile gerçekleştirilmiştir. DD13 malzeme olarak ERDEMIR 6224, S355MC malzemesi olarak ERDEMIR 4936 kalite sac kullanılmıştır.

DD13 ve S355MC sac malzemeler süspansiyon sistemlerinde farklı üreticilerin tasarladıkları geometri neticesinde kullanım olarak farklılık göstermekte olup, yan sanayi ürünlerinde karşılaşılan malzemelerdir. S355MC orijinal ana parçalara oldukça yakın mekanik özelliklere sahip olması ile yan sanayide tercih edilen diğer DD11 ve DD13 malzemelerin zamanla yerini almaktadir.

Çalışmada kullanılan her iki malzemenin kimyasal kompozisyonundaki farklılıklar yapılan spektral analiz ile belirlenmiş elde edilen sonuçlar Tablo 1'de belirtilmiştir.

Tablo 1. Spektral analiz sonuçlart

\begin{tabular}{c|c|c}
\hline & DD13 & S355MC \\
\hline$\% \mathbf{C}$ & 0.056 & 0.086 \\
\hline$\% \mathbf{S i}$ & 0.001 & 0.04 \\
\hline$\% \mathbf{P S}$ & 0.002 & 0.009 \\
\hline$\% \mathbf{M n}$ & 0.007 & 0.003 \\
\hline$\% \mathbf{T i}$ & 0.28 & 0.8 \\
\hline$\% \mathbf{A l}$ & 0.001 & 0.008 \\
\hline$\% \mathbf{N b}$ & 0.025 & 0.09 \\
\hline$\% \mathbf{V}$ & 0.001 & 0.1 \\
\hline & 0.001 & 0.03 \\
\hline
\end{tabular}

Çekme deneyleri ISO 6892-1 standardında olup minimum uzama ele alınarak hadde yönüne $90^{\circ}$ olacak şekilde gerçekleştirilmiştir. Test numunesine ait ölçü ve toleransları Şekil 3 ve Tablo 2'de görülmektedir.

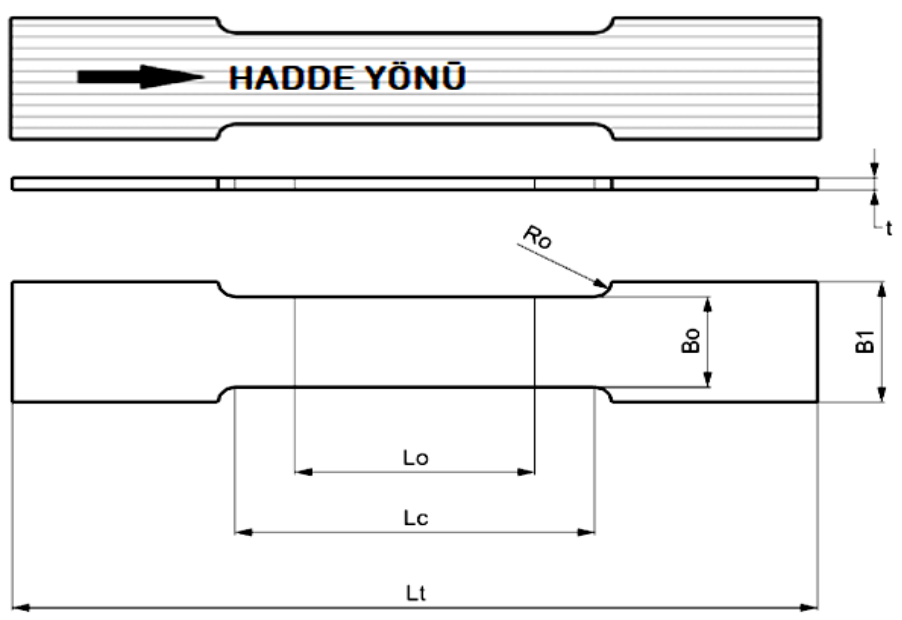

Şekil 3. Çekme testi hadde yönü ve numune ölçüleri

Tablo 2. Çekme testi numunesi ölçü ve toleransları

\begin{tabular}{l|c|c}
\hline Genişlik & Bo & 20 \\
\hline İlk Ölçü Uzunluğu & Lo & 50 \\
\hline Gövde Uzunluğu & $\boldsymbol{L c}$ & 60 \\
\hline Toplam Uzunluk & $\boldsymbol{L t}$ & 300 \\
\hline Çene Tutma Genişliği & $\boldsymbol{B} 1$ & 30 \\
\hline Kavis Yarıçapı & $\boldsymbol{R o}$ & 12 \\
\hline
\end{tabular}

Not: Ölçüler mm, İşleme toleransı $\pm 0.02 \mathrm{~mm}$ dir.

Et kalınlı $\breve{g} \boldsymbol{t}=2 \mathrm{~mm}$

Hadde yönüne $90^{\circ}$ olacak şekilde elde edilen test sonuçları Tablo 3'de görülmektedir.

Tablo 3. Çekme testi verileri

\begin{tabular}{l|c|c}
\hline & DD13 & S355MC \\
\hline $\begin{array}{l}\text { \%0,2 Akma Gerilmesi } \\
{[\mathbf{M P a}]}\end{array}$ & 252,78 & 409,21 \\
\hline $\begin{array}{l}\text { Çekme Gerilmesi } \\
{[\mathbf{M P a}]}\end{array}$ & 342,45 & 477,92 \\
\hline $\begin{array}{l}\text { Kopma Uzaması } \\
{[\%]}\end{array}$ & 47,82 & 34,98 \\
\hline $\begin{array}{l}\text { Elastisite Modülü } \\
\text { [GPa] }\end{array}$ & 14,43 & 18,22 \\
\hline
\end{tabular}

Çekme testlerinden yola çıkarak DD13 malzemesinin akma ve çekme değerleri, S355MC malzemeye oranla daha düşük olmasının yanında kopma uzamasının yaklaşık \%37 oranda daha iyi olduğunu görmekteyiz.

Şekil 4 ve Şekil 5'de malzemelere ait FLD diyagramları incelendiğinde, DD13 malzemesinin tek ve iki eksenli çekme değerlerinin S355MC'ye nazaran daha fazla şekillendirilebilir 
olduğu görülmektedir. Minör gerilmelerin (-) yönde ilerlemesi ve majör gerilmelerin $(+)$ yöndeki eğrinin sol tarafı malzemenin derin çekilebilme kabiliyetinin gösterirken, minör gerilmelerin $(+)$ yönde olup majör gerilmelerinde $(+)$ olduğu eğrinin sağ tarafinda ise malzemenin çift eksenli çekme (gerdirme) kabiliyetini göstermektedir [11].

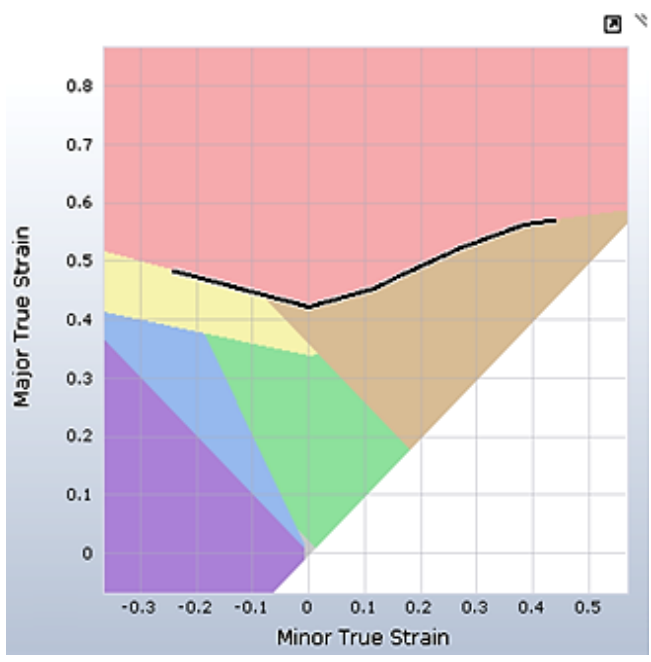

Şekil 4. DD13 FLD diyagramı

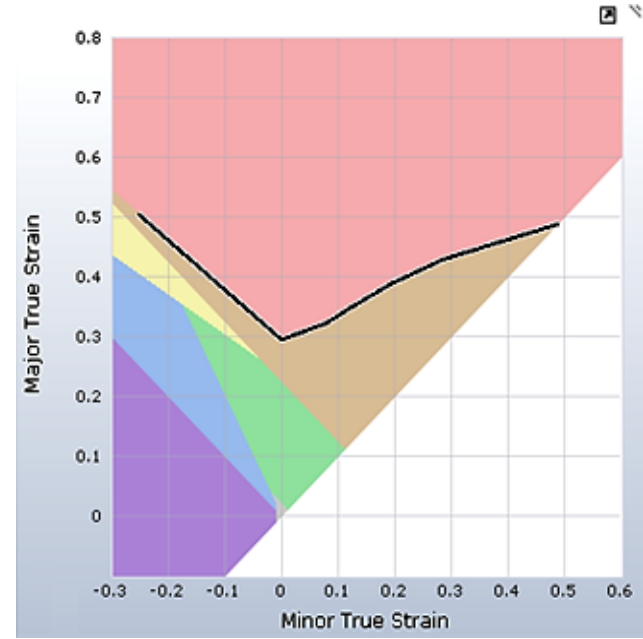

Şekil 5. S355MC FLD diyagramı

Süspansiyon sistemi elemanı olan sac salıncak kolunun üretimi genel olarak; şablon kesme/şablon delme işlemi, şekillendirme işlemi (derin-sı̆̆ çekme), varsa ara işlemler (ön form vs.), kaynaklı birleştirme, kataforez kaplama ve burçrotillerin montajı ile parça tamamlanarak kullanıcıya hazır duruma getirilmiş olur (Şekil 6).

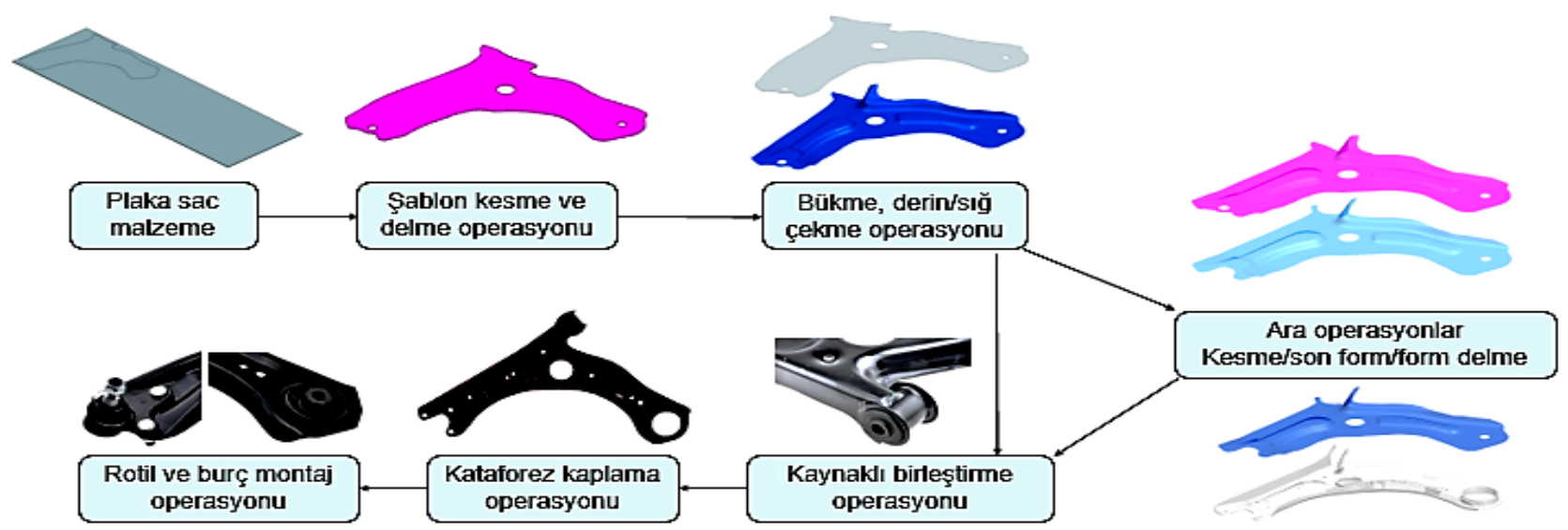

Şekil 6. Sac salıncak kolu üretim adımları

\section{Bulgular}

Yapılan analiz çalışmasında ilk geometride, her iki malzeme için de Şekil 7'deki gibi yırtılma riski ile karşılaşılmıştır. Burada kırmızı renkle belirtilen bölgeler yırtılmaya maruz kalacak bölgeler olup, şekillendirme sınır eğrilerinin üzerine çıkması durumunda yırtılacağını gösteren geometri üzerine yansıtılmış gerilmelerin görüntüsüdür.
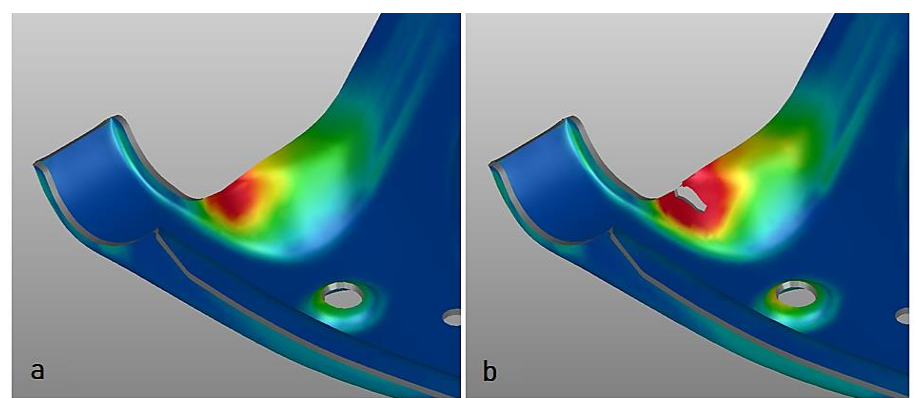

Şekil 7. a) DD13 analiz sonucu b) S355MC analiz sonucu
Yüksek yırtılma riski görülen analizde, bu bölgede oluşan tek eksenli gerilmenin malzemedeki sabit radüslerin sebep olduğu düşünülerek, yapılan geometri düzenlemeleri ile sabit tanımlı radüs ile devam eden formun (Şekil 8.a), sacın rahat hareket etmesi için değişken radüs (kenar boyunca artan radüs) tanımlamasında değişikliğe gidilmiştir (Şekil 8.b).
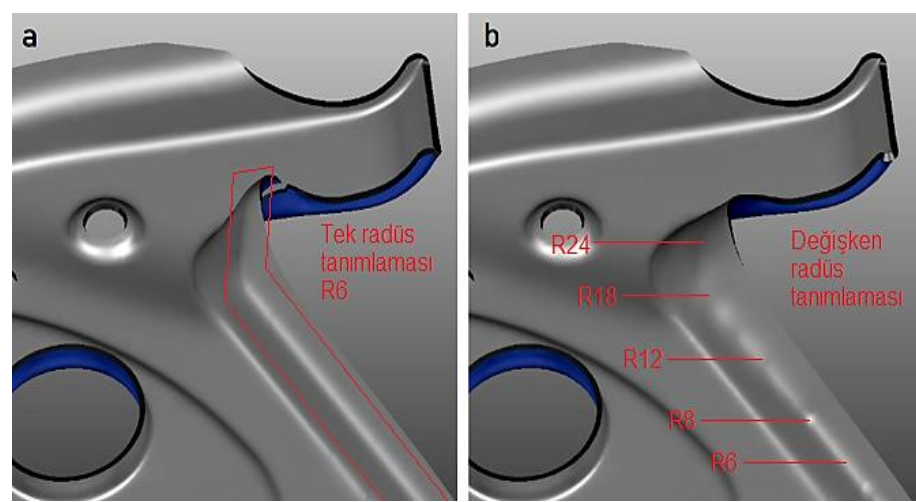

Şekil 8. a) Sabit radüslü ilk geometri b) Değişken radüslü son geometri 
Yapılan geometri değişikliği ile parçada oluşacak olan gerilmeler en düşük düzeye indirgenmiştir (Şekil 9).

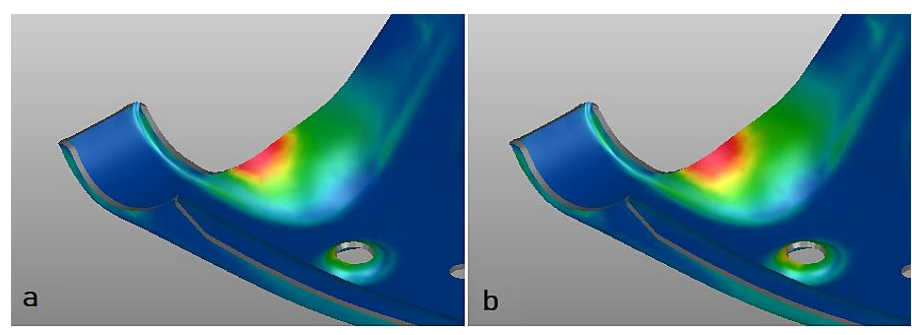

Şekil 9. a) DD13 değişken radüslü son geometri analiz sonucu

b) S355MC değişken radüslü son geometri analiz sonucu

Son geometri neticesinde imal edilen kalıpların, DD13 ve S355MC için gerçekleştirilen üretimde her iki malzemenin de gerilmelerin azaltılmasına rağmen yırtıldığı görülmüştür (Şekil 10). Bu durumun Autoform çıktıları ile tutarlı olduğu görülmüştür (Şekil 9).

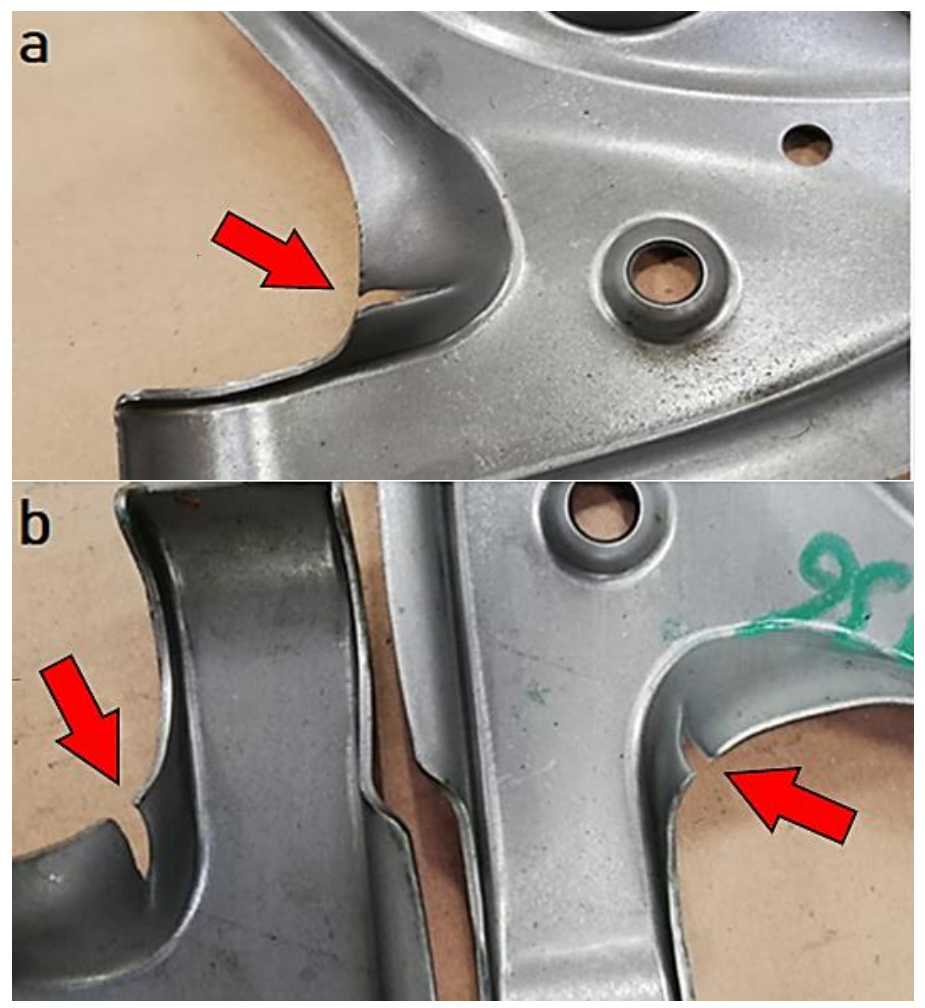

Şekil 10. a) DD13 son geometri üretilmiş parça b) S355MC son geometri üretilmiş parça

Üretimde problemin çözülebilmesi için ilk olarak yırtılma bölgesindeki (Şekil 12) şablon kesme sonrası et kalınlığında oluşan çentik etkisinin giderilmesi için özel yumuşak tip kauçuk esaslı parlatma lastiği (Şekil 11) kullanılarak parlatma işlemi gerçekleştirilmiştir. Parlatma işlemi, şablon kesme kalıbında oluşan sac kenarındaki kesme ve kopma bölgelerinin giderilmesi ile edilmiştir.
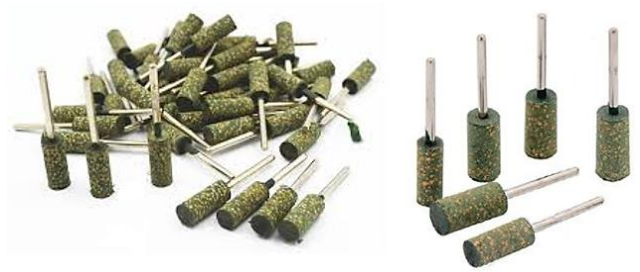

Şekil 11. Yumuşak tip kauçuklu esaslı parlatma lastiği

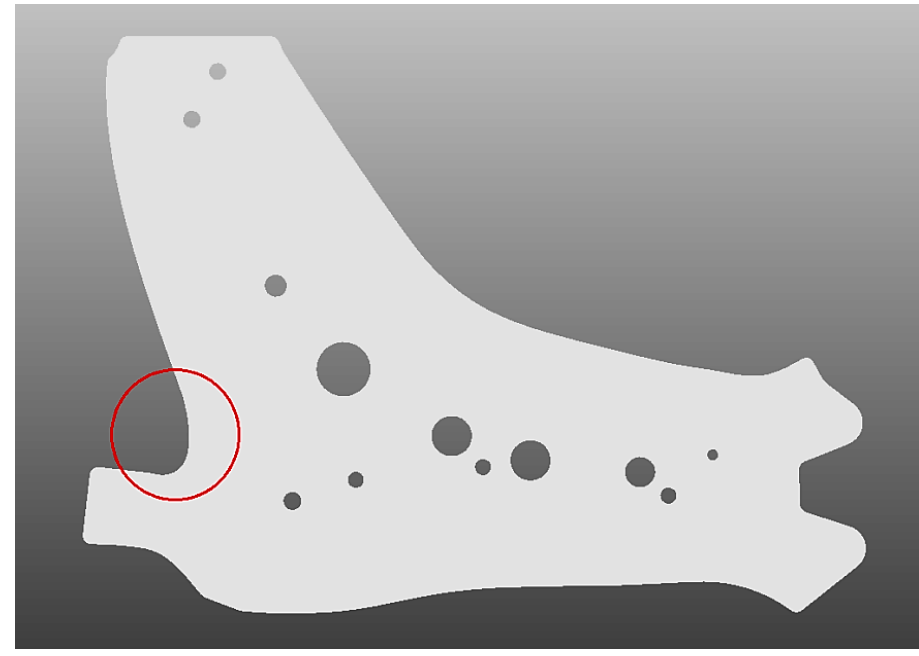

Şekil 12. Çentik etkisinin giderildiği parlatılan bölge

Yırtılma bölgesi kenarına ait et kalınlığında oluşan kesme ve kopma bölgelerinin görüntüsü Şekil 13 'te görülürken parlatma sonrası bu bölgelerin giderilip parlatıldıktan sonraki hali Şekil 14 'te verilmiştir.

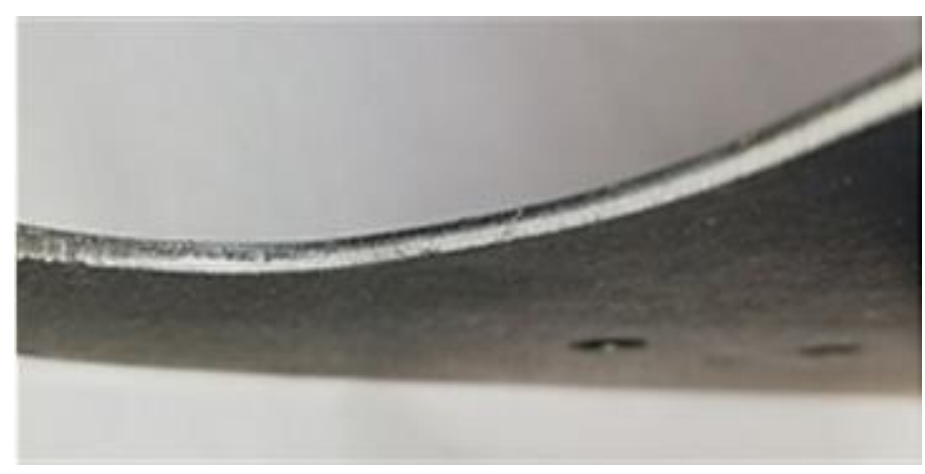

Şekil 13. Parlatma öncesi

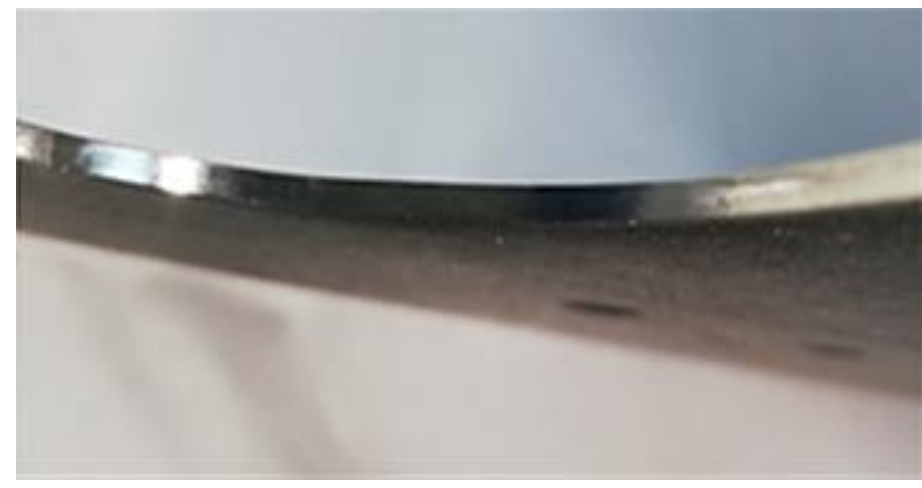

Şekil 14. Parlatma sonrası

Parlatma işlemi, şekillendirme esnasında yüzey pürüzlülüğü nedeniyle çentik etkisinin oluşmaması için tavsiye edilen ampirik çalışmalar sonucu geliştirilen bir uygulamadır. Parlatma işleminin ardından gerçekleştirilen üretimde DD13 malzemesinde yırtılma probleminin bir alt düzey olan boyun verme problemine döndüğü Şekil 15'te görülürken, S355MC için yırtılma probleminin devam ettiği Şekil 16'da görülmektedir. Boyun verme yırtılma; hasarının oluşmasından önce üretilen parçanın et kalınlığında incelme şeklinde oluşan ve çalışma koşullarında malzemenin bu noktadan kırılmasına neden olan önemli bir bir problemdir. 


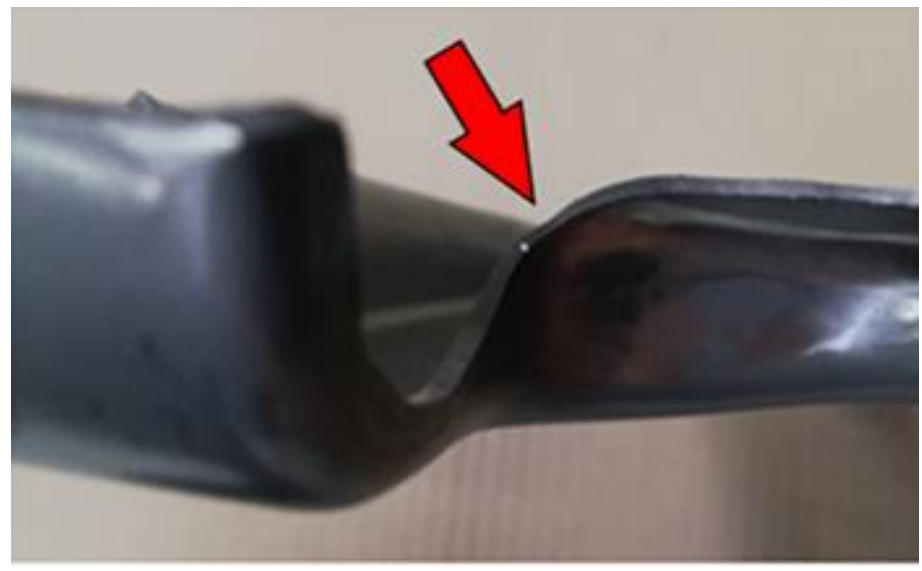

Şekil 15. DD13 Parlatma sonrası oluşan boyun verme

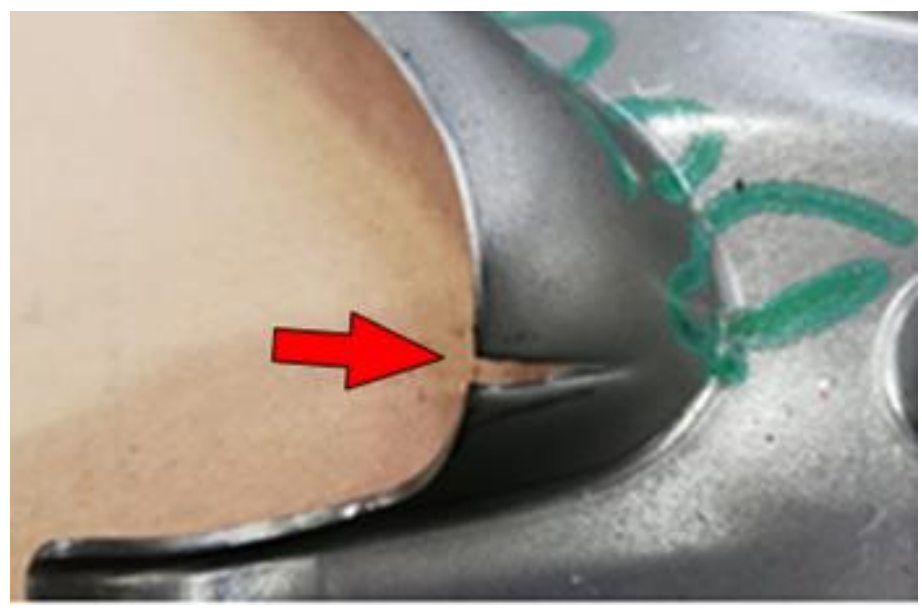

Şekil 16. S355MC Parlatma sonrast yırtılma devam ediyor

Bir diğer iyileştirme çözümü olarak kalıpta zımbayla sac parça arasındaki sürtünmenin azaltılması işlemidir. Literatürde sürtünme etkisinin şekillendirme kabiliyetine etkileri ile ilgili farklı malzeme ve farklı koşullara ait birçok araştırma yapılmıştır. Gavas ve arkadaşları [12-19] silindirik kapların derin çekilebilirliğinin artmasında sürtünme etkisi üzerinde farklı çalışmalar yapmış, çok noktalı baskı plakası ve hava etkili baskı plakası kullanarak sürtünme etkisinin azaltılması ile çekme oranlarının artırıldığı görülmüştür.

Çalışmada çentik etkisinin giderilmesi ile beraberinde sürtünmenin azaltılması için kalıp yağlayıcı olarak $0,25 \mathrm{~mm}$ kalınlığa teflon (PTFE- Politetrafloretilen) film kullanılmıştır (Şekil 17).

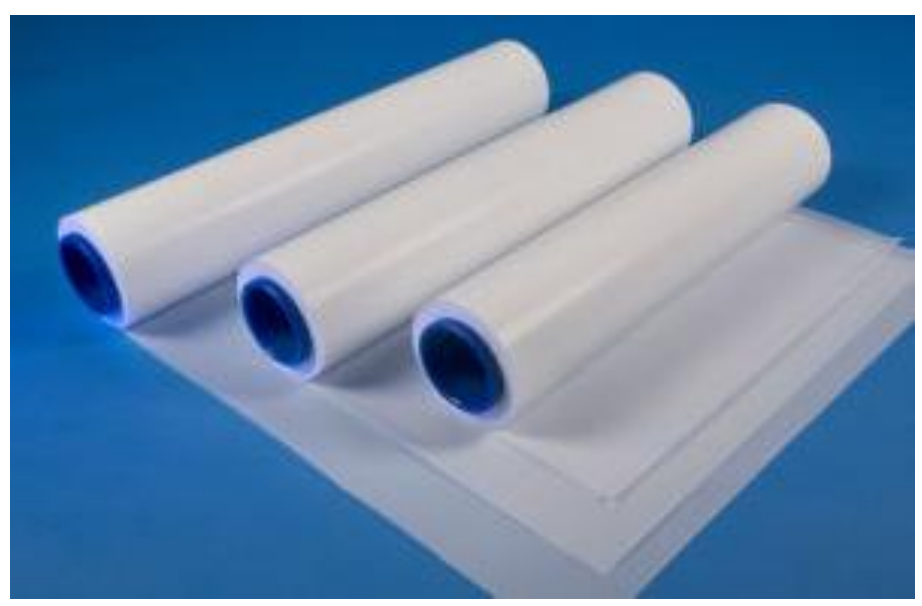

Şekil 17. Kalıp yağlayıcı (PTFE) teflon film
Teflon, kimyasal adıyla politetrafloretilen (PTFE) sürtünme katsayısı en düşük olan katı yağlayıcı malzemeler arasında olup Bong ve arkadaşları [13], yaptıkları çalışmada östenitik-ferritik paslanmaz çelik için ılık derin çekme işleminde yağlayıcı olarak kullanmışlardır.

Teflon film şekillendirme esnasında şablon halde bulunan sac malzemenin üzerine serilerek kalıp zımbası ile malzeme arasındaki sürtünmenin azaltılması abrazyon oluşumunu azaltmıştır. Yapılan kalıplama sonrasında DD13 malzemesi için yırtılma probleminin çözüldüğü görülmüştür (Şekil 18).

S355MC için yapılan kalıplama işlemi sonrasında bazı parçalarda boyun verme ile aşırı inceldiği gözlenirken parçaların çoğunda yırtılma probleminin devam ettiği tespit edilmiştir (Şekil 19).

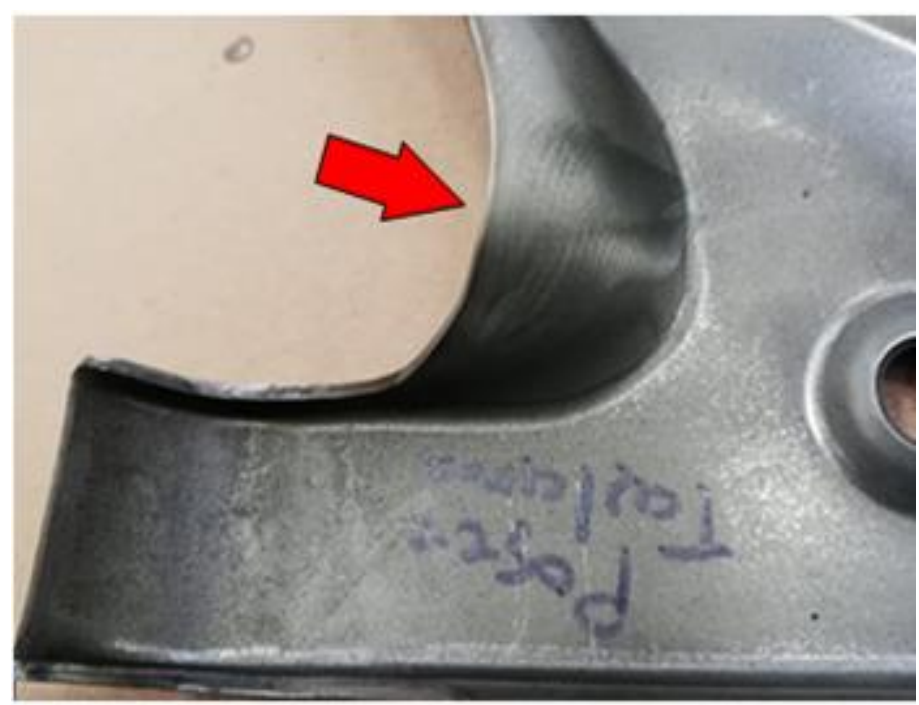

Şekil 18. DD13 Parlatma ve kalıp yağlayıcı film ile gerçekleştirilen ürün/Hasarsız ürün

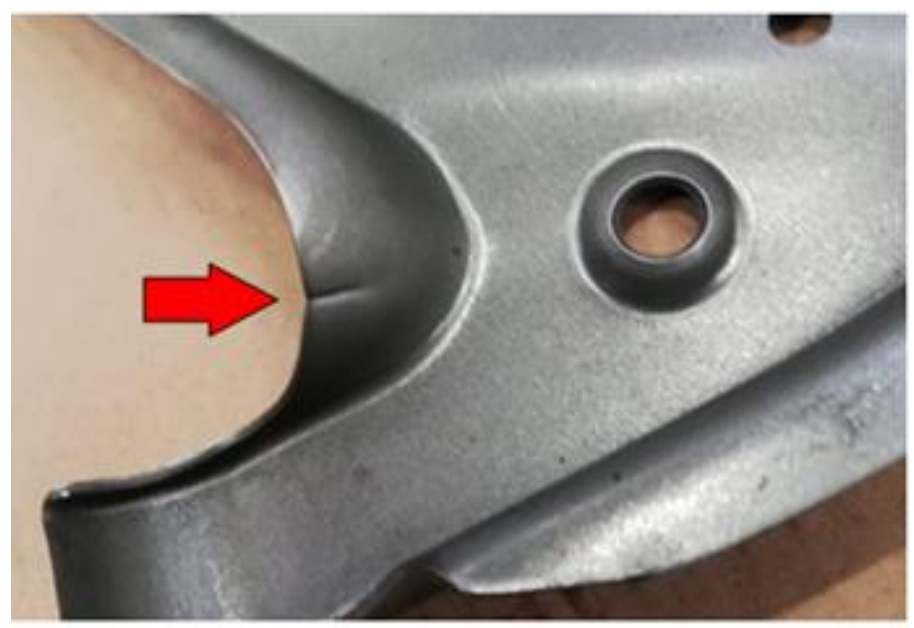

Şekil 19. S355MC Parlatma ve kalıp yağlayıcı ile gerçekleştirilen ürün

S355MC sac malzemeye, şablon halinde iken yani tüm operasyonlar öncesinde hasarlanacak kritik bölgeye isıl işlem uygulanmıştır. Böylece malzemenin şekillendirilebilirliğinin iyileştirilmesi hedeflenmiştir. Şekil 20'deki şablon haldeki parçalara ısıl işlem uygulanması görülmektedir. İşlemde kritik bölge oksi-asetilen gaz ile isıtılarak $900-1000^{\circ} \mathrm{C}$ aralığında 30 saniye süresince 1 sitılmış, sicaklık temassız termometre ile ölçülmüş ve havada soğumaya bırakılmıştır. 


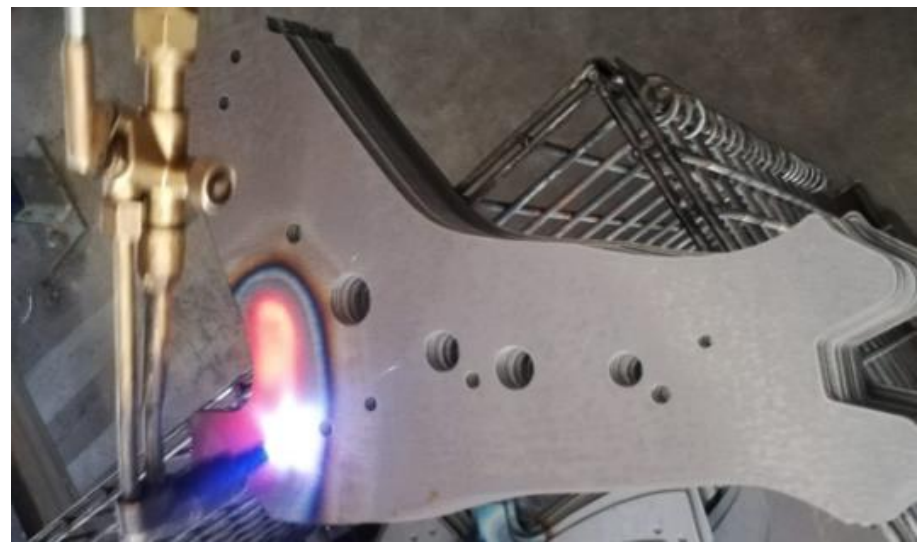

Şekil 20. S355MC şablon malzemeye bölgesel ısıl işlem uygulanması

Yapılan bu 1sıl işlem ile malzemenin 1sıtılmadan önceki mikroyapısı (Şekil 21) ve 1sıl işlem sonrası elde edilen daha homojen bir içyapının oluştuğu (Şekil 22) malzemenin üretimi esnasında oluşan kalıntı gerilmelerin giderildiği ve böylece malzemenin tokluğunun artışı dolayısıyla malzemenin şekillendirilebilirliğine önemli derecede katkı sağladığı düşünülmektedir.

Literatürde bölgesel 1sıtmanın malzeme üzerindeki etkilerini inceleyen Kahrimanidis ve ark. [14], 6000 serisi AA6014 alüminyum malzemesinin kısa süreli bölgesel 1sıtmanın farklı ısıtma yöntemleri ile malzeme üzerindeki mekanik değişimleri incelemiştir. Çalışmalarında 1sıtma hızının ve sıcaklık dağılımını etkileyen proses farklılıklarının önemini vurgulamış, bölgesel 1sıtmanın tane boyutu ve yeniden kristalleşme üzerindeki etkilerinden şekillendirilebilirliğini arttırdığını göstermişlerdir.

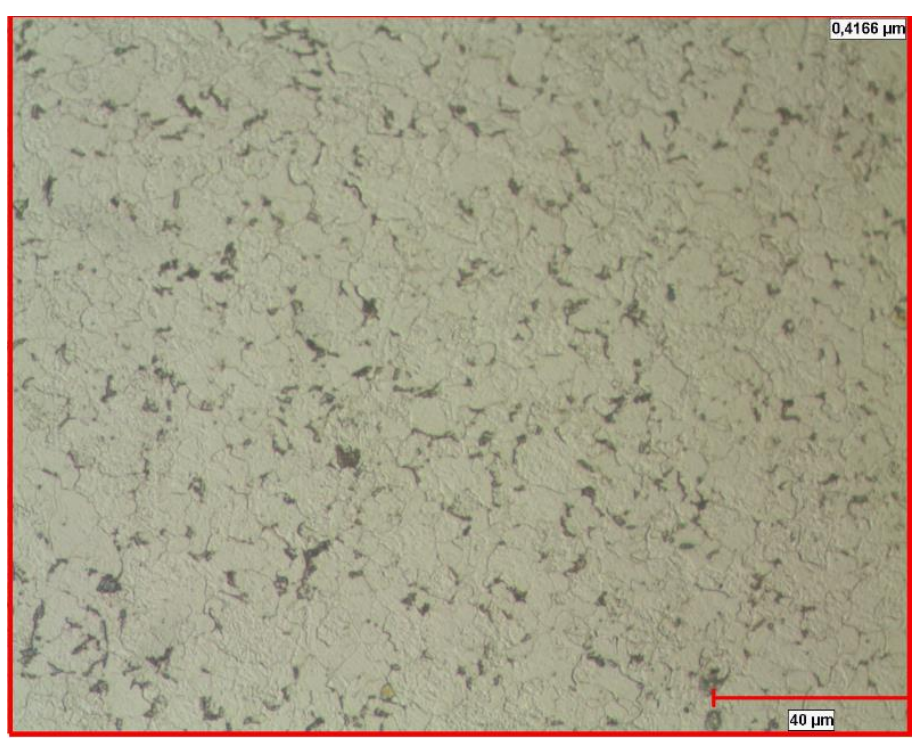

Şekil 21. S355MC mikro yapı

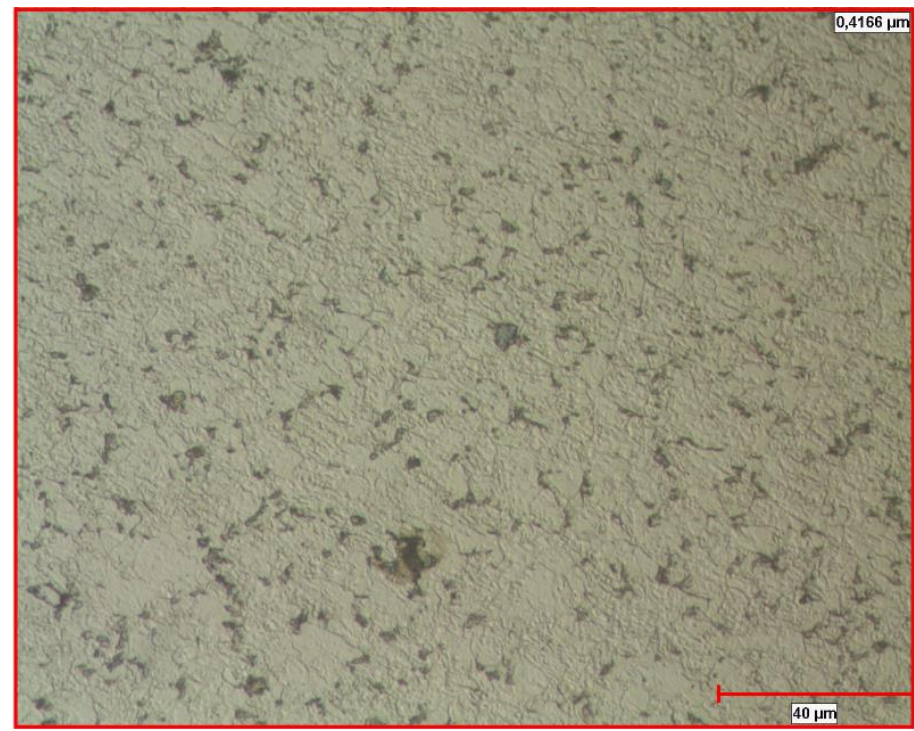

Şekil 22. S355MC Bölgesel ısıl işlem sonrası mikro yapı

S355MC malzemesi için bölgesel 1sıl işlem uygulandıktan sonra ilk olarak et kalınlığındaki çentik etkisinin giderilmesi için yapılan parlatma sonrasında numuneler basılmıştır. Yapılan deneme baskıları sonrasında yırtılmanın devam ettiği görülürken, yırtılma derinliğinin yaklaşık $4 \mathrm{~mm}$ daha azaldığı tespit edilmiştir (Şekil 23).

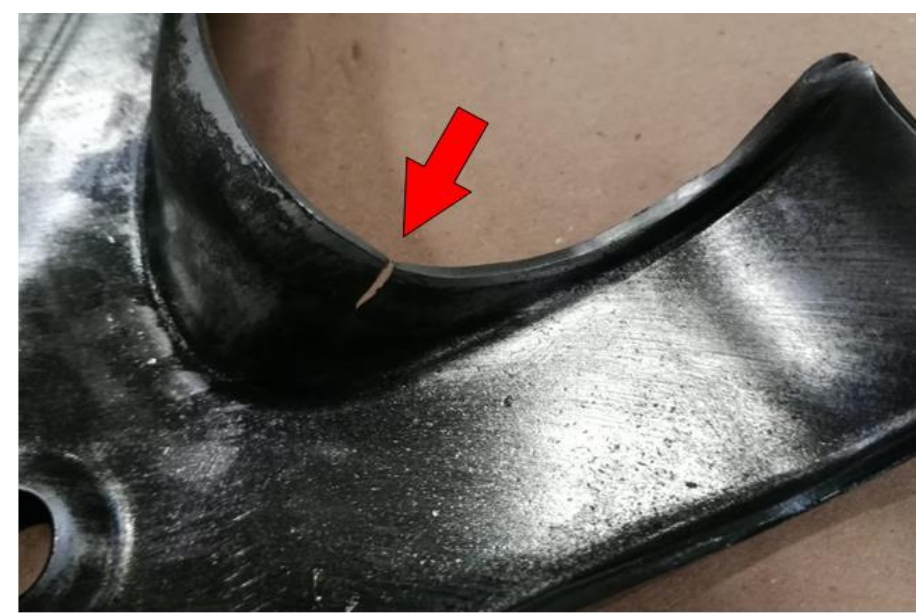

Şekil 23. S355MC malzemenin bölgesel isıl işlem ve parlatma işlemi sonrası yırtılma hasarı

Son olarak yırtılma probleminin giderilmesi çalışmasında şablonun kritik kısmın bölgesel 1sıtılması, ardından yırtılma bölgesindeki çentik etkisinin giderilmesi için yapılan parlatma işlemi ve üretimde sürtünme etkisinin giderilmesi için de kalıp yağlayıcı olarak teflon film kullanılmıştır. Yapılan denemeler sonrasında yırtılma probleminin tamamen giderildiği görülmüştür (Şekil 24).

Tablo 4. Malzemelere uygulanan proses adımları

$\begin{array}{ccc}\begin{array}{c}\text { Çentik Etkisinin Giderilmesi } \\ \text { (Parlatma) }\end{array} & \begin{array}{c}\text { Kalıp Yağlayıcı Kullanımı } \\ \text { (Teflon Film) }\end{array} & \begin{array}{c}\text { Bölgesel Isıl İşlem } \\ \text { (Isıtma) }\end{array}\end{array}$

\section{DD13}

$+$

$+$

$+$

$+$

$+$ 


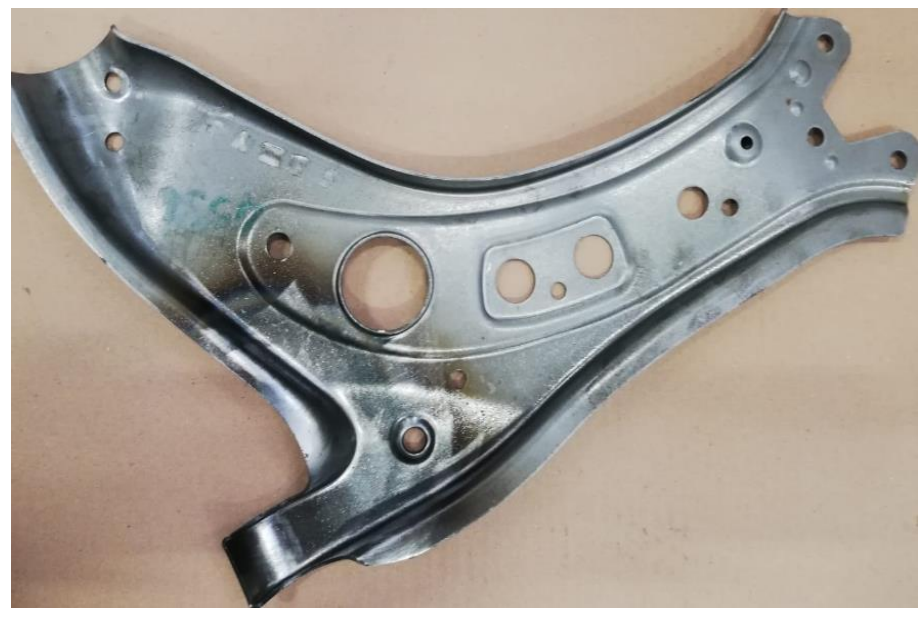

Şekil 24. S355MC malzemenin isıl işlem, parlatma ve teflon film ile üretilen yırtılma problemi çözülmüş nihai ürün

\section{Tartışma}

Gavas ve arkadaşları [12-19], silindirik kapların derin çekilebilirliğinin artırılmasında sürtünme etkisinin şekillendirilebilirliğini araştırmışlardır. Çalışmalarında sürtünme etkisinin azaltılması için çok noktalı baskı plakası kullanımında bilyelerden faydalanarak sürtünmeyi azaltmış ve hava etkili baskı plakası kullanarak malzeme ve kalıp yüzeyleri arasında hava yardımıya sürtünme etkisinin azalmasıyla şekillendirme kabiliyetinde artış olduğunu tespit etmişlerdir. Şen ve arkadaşları [15], HC300LA ve HC420LA soğuk haddelenmiş sac malzemelerin 1 lık derin çekme oranlarını farklı yağlayıcı kullanımı ile incelemiştir. Grafit sprey malzemenin kullanımı ile gerçekleştirdikleri deneylerde çekme oranı 2,30 olarak elde ederken, grafit sprey ve teflonun beraber kullanımı ile çekme oranının 2,59'a yükseldiğini belirlemişlerdir. Bu çalışmada çekme oranının yani şekillendirilebilirliğinin yağlayıcılarla arttığı tespit edilmiştir. Bahsedilen çalışmadaki elde edilen sonuçlar ile gerçekleştirilen bu çalışmada elde edilen sonuçlar paralellik göstermekteddir.

Merklein ve arkadaşları [16], AA6000 alaşımlı alüminyum serisi malzeme $5 \mathrm{sn}$ kadar ortalama $337^{\circ} \mathrm{C}$ YAG lazer ile 1 sıl işlem uygulayarak malzemenin bölgesel yumuşamasını sağlamış ve ve yapılan derin çekme ve eğme işlemlerinde şekillendirilebilirliğin arttığ1 tespit edilmiştir. Hermann ve Merklein [17], alüminyum alaşımlı bir sacın derin çekilebilirliğinin iyileştirilmesi için kısa süreli lazer 1sıl işlem uygulamış ve farklı sıcaklıklarda deneysel çalışmalar yapmışlardır. Yaptıkları çalışmada malzemenin sıcaklık artışı ile mekanik özelliklerdeki değişimi incelemiş, artan sıcaklık ile içyapının homojenliğinin artmasıyla malzemenin \% uzamasının artışına ve şekillendirilebilirliğine katkı sağladığı tespit edilmişdir.

Krupa ve Biskup [18], S355MC için kalıplamada karşılaşılan yırtılma hasarının giderilmesi için gerekli kalıp sayısını arttırarak ön şekillendirme yoluna başvurmuşlardır. Gerçekleştirilen bu çalışma ile kalıp sayısını artırmadan bahsedilen ara operasyonlarla karşılaşılan problemlerin başarılı bir şekilde çözülebileceği anlaşılmaktadır. Böylece çalışma ile ilgili endüstriyel alana önemli katkı sunarak, daha hızlı, ekonomik ve kaliteli ürün elde edilebileceği ispatlanmıştır.

Bu çalışmada, kalıp sayısını arttırmadan üretimde hangi ara operasyonlarla yırtılma probleminin çözüleceği tespit edilmiştir.

\section{Yorulma Testi ve Değerlendirilmesi}

DD13 ve S355MC sac malzemeleri için yapılan iyileştirmelerin sonunda numuneler Teknorot firması test laboratuvarında üretim şartnamesine uygun test edilmiştir. Sonsuz döngü olarak tanımlanan test parametreleri $4 \mathrm{~Hz}$ frekans ve $45^{\circ}$ açı ile $\pm 380 \mathrm{kgf}$ çevrim yükünde teste tabi tutulmuştur. Her iki malzeme için üçer adet numune ile testler gerçekleştirilmiştir (Şekil 25).

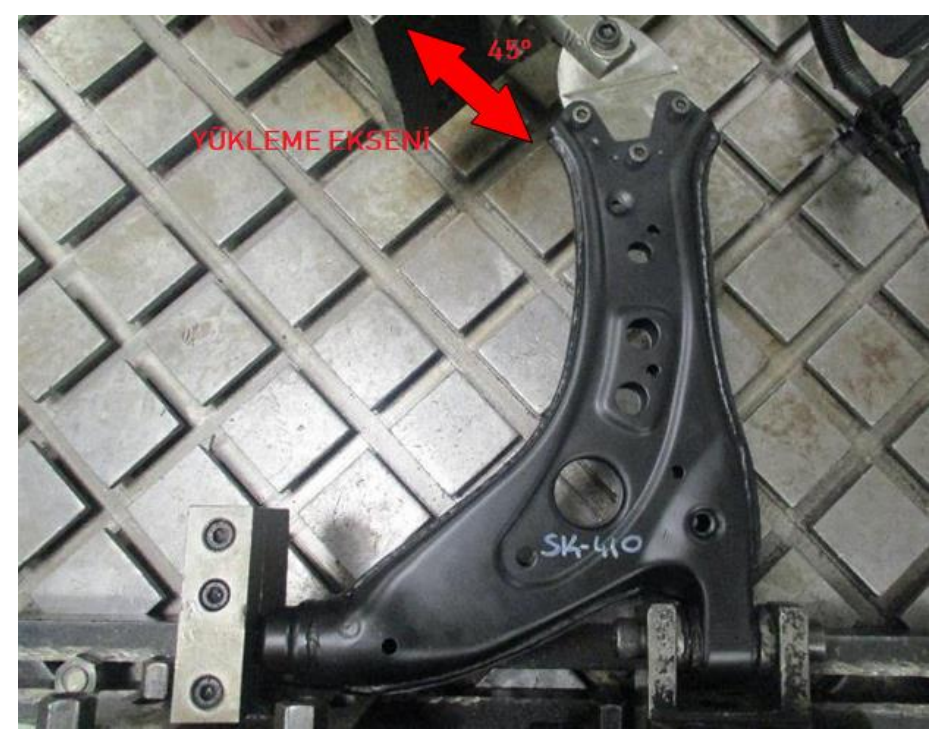

Şekil 25. Yorulma testi

Yapılan test sonucunda elde edilen ürünler, kritik değer olan 500.000 döngüyü tanımlı test parametreleri ile tamamlamıştır. Toplam çevrim sonrası yapılan kalite kontrol sonucunda numunelerde herhangi bir yırtılma hasarının oluşmadığı tespit edilmiştir.

\section{Genel Sonuçlar ve Öneriler}

Gerçekleştirilen bu çalışma ile otomotiv süspansiyon sisteminde kullanılan sac salıncak parçasının DD13 ve S355MC sac malzemeleri ile üretim sürecinde karşılaşılan muhtemel yırtılma hasarının oluşmaması için bazı çözüm yöntemleri sırayla uygulanmış, elde edilen sonuçlar aşağıda sıralanmıştır.

1. Şablon kesme operasyonu sonrasında yırtılma oluşacak bölgeye ait kenarda çentik etkisinin giderilmesi için özel yumuşak tip kauçuklu esaslı parlatma lastiği ile parlatma işlemi yapılmıştır. DD13 malzemesinde yırtılma problemi çoğunlukla boyun verme eğilimine döndüğü gözlemlenirken, S355MC malzemesinde y1rtılma probleminin devam ettiği görülmüştür.

2. Parlatma işlemine ilave olarak sürtünme etkisinin azaltılması için kalıp yağlayıcı olarak 0,25 mm kalınlığında teflon film (PTFE- Politetrafloretilen) sac şablon ile kalıp zımbası arasına serilerek kalıplama yapılmıştır. DD13 için yırtılma probleminin çözüldüğü gözlemlenirken, S355MC malzemesinin çoğunlukla boyun verdiği bunun yanında yırtılmanın az da olsa devam ettiği tespit edilmiştir.

3. Yırtılma probleminin S355MC için çözülememiş olması ile tüm operasyonlara ek olarak sac henüz şablon aşamasında iken bölgesel 1sıl işlem uygulanarak malzemeye ait mekanik özelliklerin iyileşmesi hedeflenmiş ve 1 sıl işlem sonrasında çentik etkisinin giderilmesi için parlatma işlemi yapılarak 
gerçekleştirilen üretimde malzemenin Yırtılma derinliğinin bir önceki prosese göre önemli oranda azaldığ gözlemlenmiştir.

4. Isıl işlem ve parlatma operasyonlarına ek olarak kalıp yağlayıcı teflon film kullanımı ile gerçekleştirilen üretimde ise S355MC için yırtılma probleminin tamamen giderildiği tespit edilmiştir.

5. Uygulanan çözüm yöntemlerinin başarılı olduğu ve kaliteli ürünlerin eldesini sağladığı, ürünlere uygulanan yorulma testlerin sonrasında ürünlerde herhangi bir yırtılma hasarlarının oluşmamasından anlaşılmaktadır.

Öneri olarak bundan sonraki yapılacak çalışmalar için bazı tavsiyeler aşağıda sıralanabilir:

- Malzemede oluşan çentik etkisinin daha operasyon başında oluşmaması için şablon kesme işlemi lazer kesim yöntemi ile gerçekleştirilerek çentik oluşum probleminin devam edip etmeyeceği araştırılabilir.

- Alternatif kalıp yağlayıcı arayışı ile farklı katı yağlayıcılar kullanılarak bölgesel isıl işleme gerek olmaması sağlanabilir.

- Şekillendirme sonrasında plastik deformasyonun aşırı gerçekleştiği bölgelerde, fazlaca pekleşme olup bu pekleşme derecesinin çatlağa neden olup olmadığı araştırılabilir.

\section{Teşekkür}

Bu çalışmada tüm olanakları sağlayan Teknorot Otomotiv Ürünleri San ve Tic. A.Ş’ye katkılarından dolayı teşekkür ederiz.

\section{Kaynakça}

[1] Crouse W. H., Anglin, D.L., “Automotive Brakes, Suspension and Steering”, Macmillan/McGrawHill, New York, 112-133, 1992.

[2] Fenton J., "Handbook of Automotive Powertrain and Chassis Design", Professional Engineering Publishing, London, 162, 1998.

[3] Emekli M.E., "Hafif Ticari Bir Araç İçin Yarı Aktif Süspansiyon Sistemi Tasarımı", İstanbul Teknik Üniversitesi, Türkiye, 1-133 2008.

[4] Rutci A. and Eren F.S., "Investigation of Suspension Ball Joint Pull Out Force Based on FEA Method and Experimental Study" International Symposium on Innovative Technologies in Engineering and Science, Alanya, 1002-1009, 2018.

[5] Luet D.J., "Bounding Volume Hierarchy and Non Uniform Rational B-Splines for Contact Enforcement in Large Deformation Finite Element Analysis of Sheet Metal Forming", $\mathrm{PhD}$ thesis, Princeton University Mechanical and Aerospace Engineering, 2016.

[6] Keeler S.P. and Backofen, W.A., "Plastic Instability and Fracture in Sheets Stretched Over Rigid Punches", ASM Trans. Quart., 56, 25-48, 1963.
[7] Vishwajeet R.S. ve Uday A.D. "Experimental Investigation on Forming Limit Diagram of Mild Carbon Steel Sheet", 2nd International Conference on Materials Manufacturing and Design Engineering, Procedia Manufacturing 20, 141-146, 2018.

[8] Kayalı E.S., Çimenoğlu, H. ve Akoy, M.A., "Erdemir T.A.Ş. Üretimi Sacların Biçimlenebilirliklerinin İncelenmesi”, İnceleme Raporu, İTÜ Kimya Metalurji Fakültesi, İstanbul, 2000.

[9] Gavas M., "Sac metallerin şekillendirilmesi : Kesme-bükmederin çekme-iş ve takım bağlama”, Seçkin Yayıncılık, 2017

[10] Paul S.K., "Theoretical Analysis Of Strain And Stress-Based Forming Limit Diagrams", IMechE 2013, J Strain Analysis 48(3), 177-188, 2013.

[11] Anket O., Koruvatan T., Ay İ., "Sac Malzemelerin Şekillendirilmesinde Şekillendirme Sınır Diyagramlarının Kullanımı” Politeknik Dergisi, 14(1), 39-47, 2011

[12] Gavas M., Uğraş A., "Hava Etkili Baski Plakasinin Derin Çekme İşlemlerine Etkisinin Deneysel Olarak İncelenmesi” Gazi Üniversitesi Mimarlık ve Mühendislik Fakültesi Dergisi, 25(4), 847-855, 2010.

[13] Bong H. J., Barlat F., Ahn D. C., Kim H. Y., and Lee M. G., "Formability of austenitic and ferritic stainless steels at warm forming temperature,” Int. J. Mech. Sci., 75: 94-109, 2013.

[14] Alexandera K., Daniela W., and Marion M., "Influence of a short term heat treatment by conduction and induction on the mechanical properties of AA6014 alloys", 8th International Conference on Photonic Technologies LANE 2014, 1410-1418, Sindelfingen, Germany: Daimler AG, 2014

[15] Şen N., Kurgan N., Karaağaç İ., Uluer O., "Ilık Derin Çekme Prosesinde Yağlayıcı Etkisinin Şekillendirilebilirlik Açısından Deneysel Araştırılması", Politeknik Dergisi, 19 (2), 185-193, 2016.

[16] Merklein M., Böhm W., Lechner M., "Tailoring Material Properties of Aluminium By Locak Laser Heat Treatment", Physics Procedia, 39, 232-239, 2012.

[17] Hermann J., Merklein M., "Improvement of Deep Drawability of Ultra-Fine Grained 6000 series Aluminium Alloy by Tailored Heat Treatment", Procedia Manufacturing, 15, 976983, 2018.

[18] Krupa R., Biskup K., "Pre-Forming in Sheet Metal Stamping for Part Made of High Strength Low Alloy Steel S355mc", Journal of Manufacturing Technologies, Vol. 42 No. 3, 7-10, 2017.

[19] Yaşar M., Korkmaz Z., Gavas M., "Forming sheet metals by means of multi-point deep drawing method" Materials and Design, 28(10), 2647-2653, 2007. 